\title{
Managing Vascular Surgery Emergencies and Referrals During the COVID-19 Pandemic at a Tertiary Centre in Oman
}

"Edwin Stephen, Sara S. H. Al-Adawi, Ibrahim Abdelhady, Hanan Al Mawali, Khalifa Al-Wahaibi

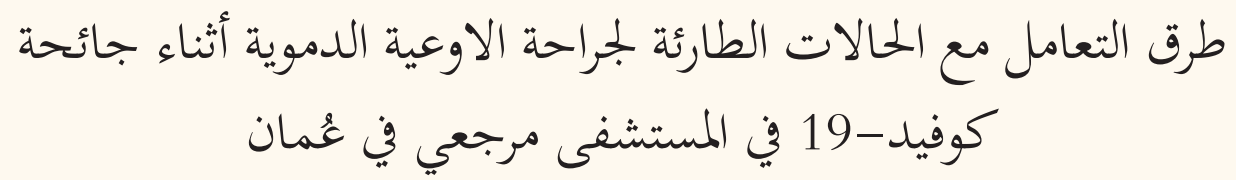

إدوين ستيفن، سارة العدوي، إبراهيم عبدالهادي، حنان المعولي، خليفة الوهيبي

ABSTRACT: Objectives: This study aimed to discuss the different challenges faced while managing emergency vascular surgery cases during the COVID-19 pandemic and how these challenges were overcome. Methods: This study details 14 emergency cases that were managed during a period of one month from mid-March to mid-April at Sultan Qaboos University Hospital, Muscat, Oman. The cases included acute limb ischaemia, critical limb ischaemia, type B dissection of the thoracic aorta, thoraco-abdominal aneurysm, critical internal carotid artery stenosis, trauma, infected arteriovenous forearm loop graft and thrombosed arteriovenous fistulas. Results: Only one patient was confirmed to have COVID-19. Five were negative for COVID-19 while the remaining eight were not tested. Various strategies on how the vascular surgical team accommodated changes in hospital protocols and nationwide lockdown are discussed in detail. Conclusions: With the judicious use of personal protective equipment and consumable surgical and endovascular devices, communication with support services and other hospitals and implementation of triage protocols, it was possible to manage vascular surgery emergencies effectively.

Keywords: COVID-19; Vascular Surgery; Emergencies; Oman.

الملخص: الهـف: هدفت هذه الدراسة لمناقشة التحديات التي واجهها فريق جراحة الاوعية الدموية في التعامل مع الحالات الطارئة الدائة

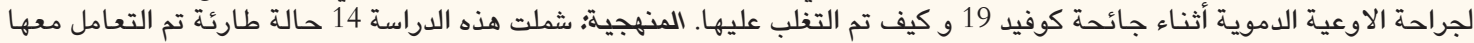

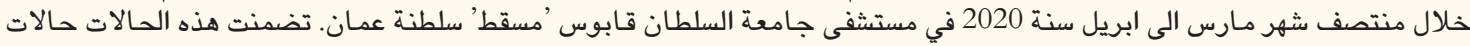

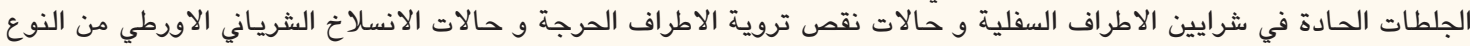

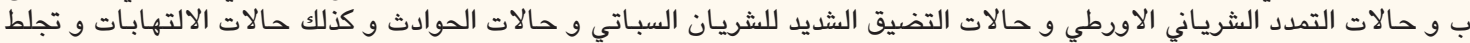

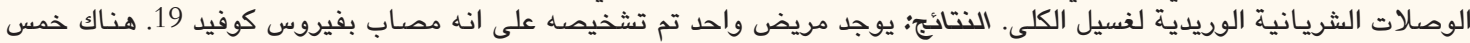

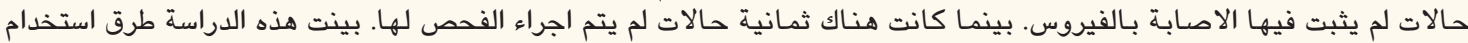

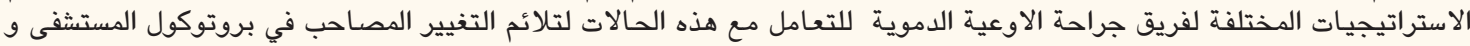

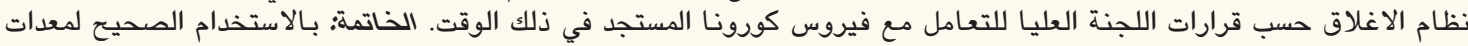

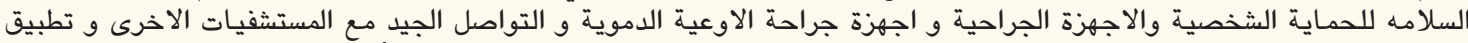

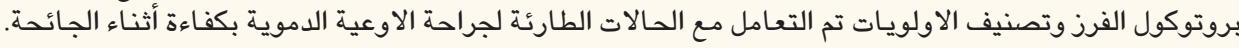
الكلمات المفتاحية: كوفيد-19؛ جراحة الاوعية الدموية؛ الحالات الطارئة؛ عُمان.

$\mathrm{O}$ $\mathrm{N}$ THE $24^{\mathrm{TH}}$ OF FEBRUARY 2020 THE FIRST two cases of COVID-19 were confirmed in Oman. In an effort to curtail the spread of the pandemic and 'flatten the curve', the international borders were shut in mid-March for non-residents and a staged lockdown between governorates was enforced from the beginning of April 2020.

All patients presenting to the Sultan Qaboos University Hospital (SQUH), Muscat, Oman, were subject to a questionnaire regarding symptoms suggestive of a COVID-19 infection and polymerase chain reaction testing was done accordingly. This article discusses how the vascular surgical team effectively managed the vascular emergency referrals during the transition period from a non-COVID-19 time to a time of COVID-19-based restrictions and protocols.

\section{Methods}

For the purpose of this study, only emergency cases referred to the vascular surgical team at SQUH between the period of $17^{\text {th }}$ of March to $16^{\text {th }}$ of April 2020 were included. A total of 14 emergency 
Table 1: Details of emergency surgeries and referrals at Sultan Qaboos University Hospital from mid-March to midApril 2020

\begin{tabular}{|c|c|c|c|c|c|c|c|}
\hline \multirow{2}{*}{$\begin{array}{l}\text { Emergency } \\
\text { presentation }\end{array}$} & \multicolumn{5}{|c|}{ Characteristic } & \multirow{2}{*}{$\begin{array}{l}\text { PCR } \\
\text { COVID-19 } \\
\text { testing } \\
\text { results }\end{array}$} & \multirow[t]{2}{*}{ Diagnosis/Management } \\
\hline & $\begin{array}{l}\text { Age in } \\
\text { years }\end{array}$ & Gender & IHR & Comorbidity & $\begin{array}{l}\text { COVID-19 } \\
\text { status symptom }\end{array}$ & & \\
\hline \multirow[t]{5}{*}{$\begin{array}{l}\text { Acute limb } \\
\text { ischaemia }\end{array}$} & 77 & $\mathrm{~F}$ & No & $\begin{array}{l}\text { DM, HTN } \\
\text { and DLP }\end{array}$ & $\begin{array}{l}\text { Cough for two } \\
\text { weeks and no } \\
\text { fever }\end{array}$ & Negative & - Femoral embolectomy \\
\hline & 43 & M & No & $\begin{array}{l}\text { ESRD, DM } \\
\text { and HTN }\end{array}$ & $\begin{array}{l}\text { Sepsis and CXR } \\
\text { suspect }\end{array}$ & Negative & $\begin{array}{l}\text { - Popliteal and tibial } \\
\text { embolectomy }\end{array}$ \\
\hline & 28 & $\mathrm{~F}$ & No & $\begin{array}{l}\text { Sickle cell } \\
\text { disease }\end{array}$ & $\begin{array}{l}\text { Sepsis and CXR } \\
\text { suspect }\end{array}$ & Negative & $\begin{array}{l}\text { - Rutherford grade } 3 \\
\text { bilateral hand and } \\
\text { forefeet } \\
\text { - On maximum inotropic } \\
\text { support } \\
\text { - Given anticoagulation } \\
\text { medication }\end{array}$ \\
\hline & 95 & $\mathrm{~F}$ & No & $\begin{array}{l}\text { DM, HTN } \\
\text { and } \mathrm{CHF}\end{array}$ & $\begin{array}{l}\text { Shortness of } \\
\text { breath and CXR } \\
\text { suspect }\end{array}$ & Negative & $\begin{array}{l}\text { - Cold forefoot and pain } \\
\text { - PTA pulse ++ } \\
\text { - CTA - PTA is only run off } \\
\text { - BMT }\end{array}$ \\
\hline & 43 & M & No & Trisomy 21 & $\begin{array}{l}\text { Shortness of } \\
\text { breath and fever }\end{array}$ & Negative & - Brachial embolectomy \\
\hline \multirow[t]{2}{*}{$\begin{array}{l}\text { Critical limb } \\
\text { ischaemia }\end{array}$} & 59 & M & Yes & $\begin{array}{l}\text { DM, HTN, } \\
\text { CKD Stage 1, } \\
\text { non-healing } \\
\text { left foot } \\
\text { wound and } \\
\text { rest pain }\end{array}$ & Asymptomatic & Not done & $\begin{array}{l}\text { - Diabetic foot } \\
\text { - SFA + PTA angioplasty } \\
\text { - Telephonic follow-up }\end{array}$ \\
\hline & 69 & $\mathrm{~F}$ & No & $\begin{array}{l}\text { CKD Stage } \\
\text { 4, DM, } \\
\text { HTN and } \\
\text { gangrenous } \\
\text { second and } \\
\text { third toes }\end{array}$ & Asymptomatic & Not done & $\begin{array}{l}\text { - SFA angioplasty } \\
\text { + stenting and PTA } \\
\text { angioplasty } \\
\text { - Amputation of } \\
\text { gangrenous toes }\end{array}$ \\
\hline $\begin{array}{l}\text { Type B } \\
\text { dissection }\end{array}$ & 65 & $\mathrm{~F}$ & No & $\begin{array}{l}\text { HTN, DM } \\
\text { and chest and } \\
\text { back pain }\end{array}$ & Asymptomatic & Not done & $\begin{array}{l}\text { - No mal-perfusion } \\
\text { - Medical management for } \\
\text { blood pressure control in } \\
\text { the cardiac ICU } \\
\text { - Outpatient follow-up }\end{array}$ \\
\hline $\begin{array}{l}\text { Thoraco- } \\
\text { abdominal } \\
\text { aneurysm }\end{array}$ & 96 & $\mathrm{~F}$ & No & $\begin{array}{l}\text { Anaemia, } \\
\text { DM, HTN } \\
\text { and history of } \\
\text { falling }\end{array}$ & Sepsis & Not done & $\begin{array}{l}\text { - Poor functional status } \\
\text { - BMT }\end{array}$ \\
\hline $\begin{array}{l}\text { Critical ICA } \\
\text { stenosis }\end{array}$ & 75 & $\mathrm{~F}$ & Yes & $\begin{array}{l}\text { Stroke, DM } \\
\text { and HTN }\end{array}$ & Asymptomatic & Not done & $\begin{array}{l}\text { - Telephonic consult } \\
\text { - Right hemiparesis } \\
\text { - Left ICA 75\% stenosis on } \\
\text { Duplex } \\
\text { - BMT and CTA }\end{array}$ \\
\hline Trauma & 22 & M & No & $\begin{array}{l}\text { Open fracture } \\
\text { of tibia and } \\
\text { fractured } \\
\text { pelvis and } \\
\text { femur }\end{array}$ & Asymptomatic & Not done & $\begin{array}{l}\text { - Left internal iliac artery } \\
\text { embolisation } \\
\text { - Ex-fix femur and tibia }\end{array}$ \\
\hline $\begin{array}{l}\text { Infected AV } \\
\text { forearm loop } \\
\text { graft }\end{array}$ & 74 & $\mathrm{~F}$ & No & $\begin{array}{l}\text { ESRD on } \\
\text { dialysis, DM } \\
\text { and HTN }\end{array}$ & $\begin{array}{l}\text { Sepsis and CXR } \\
\text { suspect }\end{array}$ & Negative & - Graft explanted \\
\hline \multirow[t]{2}{*}{$\begin{array}{l}\text { Thrombosed } \\
\text { AV fistula }\end{array}$} & 54 & $\mathrm{~F}$ & Yes & $\begin{array}{l}\text { ESRD on } \\
\text { dialysis }\end{array}$ & $\begin{array}{l}\text { Shortness of } \\
\text { breath, fever, } \\
\text { cough and } \\
\text { required NIV }\end{array}$ & Positive & $\begin{array}{l}\text { - Dialysed via a Quinton } \\
\text { line at the local hospital }\end{array}$ \\
\hline & 52 & $\mathrm{M}$ & No & $\begin{array}{l}\text { ESRD, DM } \\
\text { and HTN }\end{array}$ & Asymptomatic & Not done & $\begin{array}{l}\text { - Thrombosed AV fistula } \\
\text { with cellulitis in arm } \\
\text { - Catheter directed } \\
\text { thrombolysis and IV } \\
\text { antibiotics }\end{array}$ \\
\hline
\end{tabular}

$I H R=$ interhospital referral; $P C R=$ polymerase chain reaction; $F=$ female $D M=$ diabetes mellitus; $H T N=$ hypertension; $D L P=$ dyslipidaemia $; M=$ male; $E S R D=$ end stage renal disease $; C X R=$ chest $x$-ray; $C H F=$ congestive heart failure; $P T A=$ posterior tibial artery; $C T A=$ computed tomography angiography; $C K D=$ chronic kidney disease; SFA = superficial femoral artery; ICU = intensive care unit; BMT = best medical therapy; ICA = internal carotid artery; $A V=$ arteriovenous; NIV = non-invasive ventilation; $I V=$ intravenous. 
surgeries and referrals were included [Table 1]. The usual case volume before the pandemic was around 40-50 patients per month for elective surgical and endovascular procedures.

Ethical approval was obtained from the institutional Research Ethics Committee (MREC \#2143)

\section{Results}

Of the 14 cases, one was confirmed to be positive for COVID-19, requiring respiratory support with noninvasive ventilation. Five patients tested negative, one of whom was being managed as a potentially positive COVID-19 case until the second test revealed a negative result. The remaining eight cases did not meet the criteria set for COVID-19 testing.

\section{Discussion}

SQUH is one of two centres in Oman with endovascular and vascular surgical services in the capital city of Muscat. Elective surgical procedures were stopped from the $15^{\text {th }}$ of March 2020, with priority given to patients with malignancies and emergency cases. For example, two patients were scheduled for elective aneurysm repairs (a thoracic endovascular aortic repair and a fenestrated endovascular aortic repair) were postponed as they were in the geriatric age group with multiple comorbidities, until such a time that the pandemic was deemed to be under control. Interventional procedures (cardiac and interventional radiology) were carried out in the hybrid catheterisation laboratory.

SQUH like other hospitals around the globe, experienced a shortage in personal protective equipment (PPE). Healthcare professionals underwent a series of training sessions in donning, doffing and care of PPE. If the COVID-19 test results were expected within one hour and a patient was likely to need intervention, assessment was performed by the consultant on call, thereby reducing the use of PPE.

Anaesthetists, radiologists, technicians, nurses and porters were willing to expedite results of investigations, perform medical imaging and transfer the suspected COVID-19 patients in order to minimise exposure time despite intentional and planned reduction in staffing. This reduction was periodically assessed by the administration to ensure that patient care wasn't affected.

Inpatient transfers were limited between hospitals by facilitating visit(s) by the consultant vascular surgeons to hospitals, within the governorate of Muscat. For patients requiring a transfer, they were permitted to cross the police check-points establishing during lockdown with a referral letter from their primary hospital. Telemedicine was put to good use between doctors in the periphery who sought the opinion of the surgical team at SQUH.

Despite the above systems being in place, one of the included patients with a diabetic foot that required dressings preferred to remain as an inpatient to avoid travel between governorates. However, there were also patients with concerns who were encouraged to visit the clinic but preferred to delay their visit due to the fear of contracting the virus in hospital.

In order to reduce the inter-hospital referrals, telephonic consultation was utilised to communicate with doctors in peripheral hospitals and with patients. There were four to five consultations per day which mainly involved patients with arteriovenous fistularelated concerns, critical limb ischaemia and diabetic foot infections.

Blood is an important resource that became scarce during the COVID-19 pandemic. Donors were reluctant to go to the blood donation centres for fear of contracting the virus. In a patient who presented with trauma massive a blood transfusion was required; the relatives of the patient had to be actively encouraged to donate blood and re-assured that precautions were in place to minimise person-to-person contact.

Disposable hardware for endovascular procedures that are normally shipped from abroad were limited due to the initial closure of air- and seaports. There was discussion about reuse of endovascular hardware. These were put in abeyance until standard operating procedures and ethical approvals were in place. Meanwhile, cases that required endovascular interventions were kept on-hold unless emergent. The result was postponement of all elective vascular cases that included aortic aneurysms, thoracic outlet syndrome, varicose veins, arteriovenous fistula creation and fistulogram/fistuloplasty.

Triage protocols, as suggested by the Society of Vascular Surgery (SVS) and the National Health Service (NHS), have been helpful to SQUH in triaging patient care. ${ }^{1,2}$ The impact of the COVID-19 pandemic on the vascular surgery service at SQUH is comparable to that on other surgical specialties at SQUH and elsewhere ${ }^{3}$

\section{Conclusion}

During the COVID pandemic, challenges faced in managing vascular surgical cases and referrals were overcome effectively at SQUH. These included the judicious use of PPE, better communication in the midst of limited support service staff and reducing 
inter-hospital transfer of in-patients. Protocols such as those published by the SVS and the NHS have helped the surgical team of SQUH triage its patients better.

\section{CONFLICT OF INTEREST}

The author declares no conflicts of interest.

\section{FUNDING}

No funding was received for this pilot study.

\section{References}

1. Society of Vascular Surgery. Vascular Surgery Triage by Tier Class. From: https://vascular.org/news-advocacy/covid-19-resources Accessed: Aug 2020

2. American College of Surgeons. COVID-19 Guidelines for Triage of Vascular Surgery Patients. From: https://www.facs. org/covid-19/clinical-guidance/elective-case/vascular-surgery Accessed: Aug 2020

3. Hemingway JF, Singh N, Starnes BW. Emerging practice patterns in vascular surgery during the COVID-19 pandemic. J Vasc Surg 2020; 72:396-402. https://doi.org/10.1016/j.jvs.20 20.04.492. 